\title{
Market Timing And Selectivity: An Empirical Investigation Into The Features Of Greek Mutual Fund Managers
}

Nikolaos Philippas, (E-mail:philipas@unipi.gr), University of Piraeus

\begin{abstract}
This paper is an empirical assessment of the performance of mutual fund managers in terms of "market timing" and "selectivity", within the framework suggested by Treynor and Mazuy (1966) and Henriksson and Merton (1981). The relevant data set is a balanced panel of nineteen Greek managers, over a sixty-month period. Empirical evidence does not provide support for correct timing, irrespectively of how the returns of the market index are calculated. It is interesting to note that using the Total Performance Index reduces the ability of managers for selectivity. This result holds for both the models utilized in our study.
\end{abstract}

\section{Introduction}

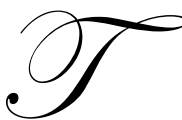

he importance of mutual funds in financial markets has literally sky-rocketed over the past fifteen years worldwide. This phenomenon can be attributed to the unique benefits that mutual funds offer to individual investors ${ }^{1}$. During 2001, more than fifty four thousand mutual funds existed worldwide, which corresponds to 14 trillion euro ${ }^{2}$. In Greece, the evolution of mutual funds market has been impressive. In 1985 there were only two government controlled mutual funds which managed 4 billion drachmas. Today there exist 265 mutual funds of all types managing 10 trillion drachmas (about 30 billion euro).

As a result of this widely documented trend, the performance of portfolio managers has become an increasingly important issue among financial analysts. From a social perspective it is important to know whether the professional managers of Mutual Funds add value to the portfolios they manage or whether they merely create excessive transaction costs through their active management. At the micro level it is important to know how to identify a portfolio manager with the ability to add value to the portfolio he manages. As a corollary, the ability to increase returns based on better forecasting ability would be a violation of the efficient market hypothesis and would have far reaching implications for the theory of finance ${ }^{3}$.

The majority of the studies for mutual funds performance have employed a method developed by Jensen (1968, 1969) and later refined by Black, Jensen and Scholes (1972) and Blume and Friend (1973). These methods compare a particular manager's performance with that of a benchmark index. However these approaches are subject to certain limitations. Firstly they are based on the assumption that the risk level of the portfolio under consideration is stationary through time and secondly they fail to separate the ability of the managers in terms of market timing and selectivity. According to Fama (1972) the performance of a fund manager can be attributed to both market timing ability and security selection ability (selectivity). The former refers to the macroforecasting ability of managers to forecast changes in the macroeconomic environment in order to change the portfolio beta and maximize its future return. The later pertains to the microforecasting ability of managers selecting undervalued assets.

Readers with comments or questions are encouraged to contact the author via email. 
In what follows the market timing and selectivity performance characteristics of the majority of Greek mutual funds is empirically examined over the period from 1/1/1993 to 31/12/1997. Section II of the paper describes the development of Greek mutual funds industry. Section III reviews the relevant theoretical models and section IV discusses the relevant empirical studies. Section V describes the data used along with the definition of variables employed. In section VII the empirical results are presented and analyzed. Section 7 concludes the paper.

\section{The Greek Mutual Funds Industry}

The mutual funds industry was established in Greece in 1972 with the introduction of two balanced funds. However, a series of economic and political events caused a recession in the stock market. As a result the growth of the mutual funds industry was delayed. Over the next fifteen years no other mutual fund was introduced. In 1989, investors turned their attention to the mutual fund industry. This was mainly due to institutional changes in the Greek capital market and the positive behavior of the Athens Stock Exchange. During the following years, the mutual funds industry continued to expand containing 208 mutual funds by the end of 1999. Greek mutual funds are classified as (a) money market funds, which invest mainly in the money market, (b) bond funds investing mainly in bonds, (c) equity funds, investing mainly in common stocks, (d) balanced type, investing both in stable stocks and bonds, (e) special type, investing in stocks that belong only to a specific industry or branch of the economy.

Greek fund managers are young (35 years old on the average), with a spread from 30 to 50, relatively inexperienced and very mobile across funds. Most of them have a master's degree, but few have completed an MBA. In some cases the fund does not have a manager and investment strategies are planned and executed by a committee ${ }^{4}$.

In the appendix, table 7 presents the evolution of mutual funds market in Greece for the period 1985 1999. Table 8 shows total deposits, the market value of the firms traded in the Athens Stock Exchange and the total assets of the Greek mutual funds, during the period 1991 - 1999. Finally, Table 9 contains the total assets and the number of mutual funds in Greece during the same period. During the last few years we observed a swing by investors from deposits and bonds to equity investments. This was mainly due to the lowering of the interest rates and the substantial increase in share returns.

\section{Models of selectivity and timing}

Jensen $(1968,1969)$ formulated a return-generated model to measure performance of managed portfolios:

$\mathrm{R}_{\mathrm{pt}}=\alpha_{\mathrm{p}}+\mathrm{b}_{\mathrm{p}} \mathrm{R}_{\mathrm{mt}}+\mathrm{u}_{\mathrm{pt}}$

where $R_{p t}$ is the excess return (net of the risk free rate) of the $p^{\text {th }}$ portfolio, $R_{m t}$ is the excess return (net of the risk free rate) of the market portfolio, $\alpha_{p}$ is a measure of security selection ability, $b_{p}$ is the beta coefficient of the portfolio $\mathrm{p}, \mathrm{u}_{\mathrm{pt}}$ is a random error which has expected value of zero and constant variance and $t$ denotes time. This specification assumes that the risk level of the portfolio under consideration is stationary through time and ignores the market timing skills of the managers. Indeed, portfolio managers may shift the overall risk composition of their portfolio in anticipation of broad market movements.

Several methods have been proposed in the literature for the evaluation of the selectivity and timing abilities of portfolio managers, using only the observed time series of realized returns on the managed portfolios ${ }^{5}$. Treynor and Mazuy (1966) added a quadratic term to equation (1) to test for market timing skill. They argued that if a manager can forecast market returns, he will hold a greater proportion of the market portfolio when the return of the market is high and a smaller proportion when the return is low. Thus, the portfolio return will be a nonlinear function of the market return as follows:

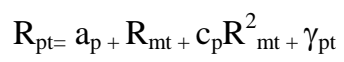


A statistically significant positive value of $c_{p}$ would imply positive market timing skill ${ }^{6}$.

The theoretical construct for the Up/Down model was established by Merton (1981) and Henriksson and Merton (1981). To examine the market timing ability of portfolio managers, Henriksson and Merton propose that the portfolio beta is cast as a binary variable, constrained to one value during up markets and another value during down markets, as follows:

$R_{p t}=\alpha_{p}+b_{p d} R_{m t}+u_{p t}$ for all $t$ where $R_{m t} \leq 0$

$R_{p t}=\alpha_{p}+b_{p u} R_{m t}+u_{p t}$ for all $t$ where $R_{m t}>0$

Which can be combined to form the dummy variable regression:

$R_{p t}=\alpha_{p}+b_{p d} R_{m t}+b_{p o} R_{m t} D_{u t}+u_{p t}$

where $R_{p t}, R_{m t}$, have already been defined, $D_{u t}$ is a dummy variable and is equal to one if $R_{m t}$ is greater than zero and to zero otherwise and $\mathrm{u}_{\mathrm{pt}}$ is a zero mean white noise process.

Assuming the capital asset pricing model of Sharpe (1964), Lintner (1965), and Mossin (1966) holds, then $\alpha_{p}$ is the selectivity parameter, $b_{p u}$ is the systematic risk during up markets and $b_{p d}$ during down markets. The slope coefficient $b_{p o}$ equals the difference for portfolio $p$ between its up and down market beta $\left(b_{p u}-b_{p d}\right)$. The macroforecasting ability of the portfolio manager can be evaluated with a t-test on $b_{p o}$ corresponding to the null hypothesis $b_{p o}$ $=0$. A significantly positive (non positive) $b_{\mathrm{po}}$ implies that the manager is a superior (inferior) macroforecaster. While the above multiple regression methods are easy to apply, statistical inference requires care. As pointed out by Henriksson and Merton (1981) the managed portfolio's return will exhibit conditional heteroscedasticity because of the fund managers attempt to time the market, even when stock returns are serially uncorrelated and identically distributed through time ${ }^{7}$.

The hypothesis tested and the anticipated results for the majority of mutual funds, according to international evidence $^{8}$, are provided in Table 1.

Table 1

\begin{tabular}{|l|l|}
\hline Hypothesis & Anticipated results \\
\hline Treynor-Mazuy Model & \\
\hline$\alpha_{p}=0$ & Reject \\
\hline$c_{p}=0$ & Accept \\
\hline Henriksson-Merton Model & \\
\hline$\alpha_{\mathrm{p}}=0$ & Reject \\
\hline$\beta_{\mathrm{po}}=0$ & Accept \\
\hline
\end{tabular}

\section{Review of past empirical studies}

The only research conducted in Greece that uses the Treynor - Mazuy model for the evaluation of performance for mutual funds is found in Mylonas (1999). The estimation results refer to 10 mutual funds of balanced and equity type for the period $1993-1994$ and 12 mutual funds of balanced and equity type 1995 - 1996 using for the market portfolio the official ASE index. According to these findings it cannot be argued that mutual fund managers exhibit significant timing ability. Empirical work worldwide with quadratic regressions has been limited and somewhat disappointing. Treynor and Mazuy (1966) using annual returns for 57 open end mutual funds, find that the hypothesis of no market timing ability can be rejected with $95 \%$ confidence for only one of the funds.

Lehmann and Modest (1987) combined the APT performance evaluation method with Treynor and Mazuy model. They found statistically measured abnormal timing and selectivity performance by mutual funds. They also found that performance measures are quite sensitive to the benchmark chosen and a large number of negative selectivity measures. Cumby and Glen (1990) examined the performance of a sample of 15 US based internationally diversified mutual funds for the period 1982 - 1988 using (among others) the Treynor - Mazuy model. The results show that there exists a perverse timing effect. Coggin - Fabozzi - Rahman (1993), using Treynor - Mazuy (1966) 
and Bhattacharya - Pfleiderer (1983) models, examined the performance for a random sample of 71 US equity pension fund managers for the period January 1983 through December 1990. The results suggest that pension fund managers are on average better stock pickers than market timers. More specifically, the average selectivity measure is positive and the average timing measure is negative regardless of the choice of benchmark portfolio or estimation model.

Henriksson (1984) examined the market timing performance of 116 mutual funds, using monthly data from February 1968 to June 1980 . He found that only three funds (one fund) had market timing ability at the 5\% (1\%) confidence level. He also found evidence of dynamic heteroscedasticity (GARCH effects). However the correction for heteroscedasticity in the regression model did not alter his conclusions. Chua and Woodward (1986) carried out the same test for Canadian, US and UK funds for the period 1973 - 1983. They found that the market timing performance of the mutual funds was in general poor. Chang and Lewellen (1984) using the Henriksson - Merton model examined monthly returns of 67 mutual funds during the period January 1971 - December 1979 using the Henriksson - Merton parametric test. They ignore the presence of heteroscedasticity, relying on the assumption on the results obtained by Henriksson that the correction for heteroscedasticity did not change the nature of conclusion. They did not find evidence that funds were systematically timing the market. If anything there seems to be evidence of negative timing. The application of this technique to a multi - portfolio benchmark in Connor and Korajczyk (1991) reveals similar results

Sinclair (1990) examined the market timing ability of managers of 16 Australian pooled superannuating funds from January 1981 to December 1987. The return performance of market timing abilities of 15 out of the 16 funds was significantly negative indicating that the timing ability is perverse.

Koh, Phoon and Tan (1993) used both parametric (Henriksson - Merton (1981)) and non-parametric criteria (Henriksson-Merton (1981), Henriksson-Lessard (1982)) to examine market timing abilities of fund managers vis-à-vis 6 mutual funds as well as 4 investment companies in Singapore. The use of non-parametric criteria led to the conclusion that market timing was achieved whereas application of non-parametric criteria led to opposite conclusions. The authors tried to reconcile the empirical results and were eventually led to the conclusion that market timing abilities for the Singapore fund managers could not be disregarded ${ }^{9}$. Kon (1983) using switching regression techniques empirically examined the performance of mutual funds. Of 37 funds, 14 had overall timing estimates that were positive but none was statistically significant. Lockwood and Kadiyala (1988), develop a generalization of the Hildreth and Hoyck (1968) random coefficient model for use in evaluating the macroforecasting ability of portfolio managers. In this model the superior manager adjusts beta period by period according to changing market conditions. The authors examined monthly returns for 47 US mutual funds throughout the 192 month period from January 1964 through 1979. The conclusions include the following: Fund managers fail the suggested macroforecasting test, betas change randomly in many funds and certain funds exhibit superior microforecasting.

More recently Gallo and Swanson (1996) considered a series of international mutual funds in order to determine - among others - time management skills of the fund managers. According to the empirical results obtained, the particular fund managers are not market timing capable, although they did show selectivity skills.

Using a different methodology than the one followed by Treynor - Mazuy and Henriksson - Merton, Daniel et al (1997) examining over 2500 equity funds from 1975 to 1994. Their results show that mutual funds, particularly aggressive-equity funds, exhibit some selectivity ability but that funds exhibit no characteristics of timing ability.

\section{Empirical application}

Monthly returns for all Greek mutual funds (balanced and equity type) are examined. To be included, each fund must have existed throughout the 60 month period from January 1993 through December 1997. The final sample consists of 19 mutual funds the assets of which account for $70 \%$ of the total assets of the relative categories ${ }^{10}$. The return data include dividends as well as capital gains and losses. The market portfolio is measured by the official General Index of the Athens Stock Exchange. It should be noted that since the official General index does not in- 
clude dividends, a new index that incorporates dividends, constructed by us and named Total Performance Index (TPI), is employed. It is interesting to point out that the omission of dividends from the Athens Stock Exchange General Index underestimates its real return and is biased in favor of fund managers ${ }^{11}$. In order to measure the risk free rate three-month Treasury bill rates have been used. ${ }^{12}$

Before formally examining the market timing and selectivity abilities of Greek mutual fund managers we consider their performance in terms of average returns, both unadjusted as well as risk adjusted.

Table 2

\begin{tabular}{|l|c|c|}
\hline \multicolumn{3}{|c|}{$\begin{array}{c}\text { Total Return and Jensen's Measure for Greek } \\
\text { Mutual Fund Industry for the period 1993 - 1997 }\end{array}$} \\
\hline Mutual Fund & $\begin{array}{c}\text { Jensen's } \\
\text { Measure }\end{array}$ & Total Return \\
\hline Midland Equity Fund & $12.44 \%$ & $70.39 \%$ \\
\hline Hambros Equity Fund & $6.51 \%$ & $46.65 \%$ \\
\hline Helvetia Balanced Fund & $2.65 \%$ & $22.31 \%$ \\
\hline Alpha Equity Fund & $1.81 \%$ & $25.85 \%$ \\
\hline Interamerican Equity Fund & $1.70 \%$ & $29.58 \%$ \\
\hline Dilos Balanced Fund & $1.52 \%$ & $26.60 \%$ \\
\hline Alpha Balanced Fund & $0.59 \%$ & $11.59 \%$ \\
\hline Delfi Balanced Fund & $0.43 \%$ & $12.85 \%$ \\
\hline Total Performance Index & $0.00 \%$ & $28.60 \%$ \\
\hline Kosmos Invest Equity Fund & $-1.33 \%$ & $7.87 \%$ \\
\hline Ethniki Asfalistiki Balanced Fund & $-1.92 \%$ & $3.83 \%$ \\
\hline Dilos Blue Chips Fund & $-2.01 \%$ & $19.90 \%$ \\
\hline Nationale Nederlanden Equity Fund & $-3.15 \%$ & $10.96 \%$ \\
\hline Aspis Balanced Fund & $-3.92 \%$ & $-4.35 \%$ \\
\hline International Balanced Fund & $-4.04 \%$ & $-3.74 \%$ \\
\hline A.S.E. General Index & $-5.20 \%$ & $5.88 \%$ \\
\hline Ermis Dynamic Fund & $-6.17 \%$ & $-6.08 \%$ \\
\hline Interamerican Hellenic Balanced Fund & $-6.88 \%$ & $-19.26 \%$ \\
\hline Europaiki Pisti Balanced Fund & $-7.52 \%$ & $-10.85 \%$ \\
\hline Ermis Balanced Fund & $-9.83 \%$ & $-33.63 \%$ \\
\hline Doriki Equity Fund & $-10.33 \%$ & $-23.25 \%$ \\
\hline
\end{tabular}

Based on total returns most managers would claim significant managerial abilities. However, if we consider risk - adjusted returns (Jensen's measure), it turns out that only two funds (namely Midland and Hambros Equity Funds) could seriously claim above - average performance. Overall, these results show that the performance of most mutual funds is not as great as mutual funds advertise.

In what follows, econometric results pertaining to the models of Treynor - Mazuy and Henriksson Merton are presented and assessed. The results presented in Tables (3) and (4) are obtained form the estimation of the Treynor - Mazuy model employing the Newey - West method. The benchmark portfolio is approximated by the Athens General Index (Table 3) and the Total Performance Index including dividends (Table 4). All the beta coefficients are statistically significant, irrespective of the approximations used with respect to the market portfolio. According to empirical results set forth in Table

(3), fifteen fund managers had positive selectivity coefficient whereas in four cases the coefficient was negative. Out of the fifteen positive coefficients four are significant at 5\%, whereas none of the negative coefficients is significant. As far as the market timing coefficient is concerned, it has been found to be positive in the case of five fund managers (one is statistically significant) whereas it was negative for the rest fourteen (of which four are statistically significant). The use of Total Performance Index has altered the results.

According to Table 4, the number of mutual funds with positive selectivity coefficient is drastically reduced a mere five such cases were found in all, of which only one being statistically significant. On the other hand, there are fourteen negative coefficients two of which are found to be statistically significant. Seven mutual funds have rated positive as far as market timing is concerned (one was statistically significant) whereas twelve mutual funds rated negative (five were found to be statistically significant). Tables (5) and (6) present the results obtained from the estimation of the Henriksson - Merton model, applying the Newey - West method. All betas are found to be statistically significant, irrespective of the approximations used for the market portfolio. 
Table 3

Summary Results from the Treynor - Mazuy model for the period 1993 - 1997 with correction of heteroscedasticity according to the Newey - West method:

$R_{p t}=a_{p}+b_{p} R_{m t}+c_{p} R_{m t}^{2}+u_{p t}$

\begin{tabular}{|c|c|c|c|c|c|c|}
\hline Parameter & Positive & Negative & Statistica & gnificant $*$ & Statistica & Insignifican \\
\hline & & & Positive & Negative & Positive & Negative \\
\hline$\alpha_{p}$ & 15 & 4 & 4 & - & 10 & 5 \\
\hline$b_{p}$ & 19 & - & 19 & - & - & - \\
\hline$c_{p}$ & 5 & 14 & 1 & 4 & 4 & 10 \\
\hline$\alpha_{p}:$ Selectivi & neter & & & & & \\
\hline $\mathrm{b}_{\mathrm{p}}:$ Beta & & & & & & \\
\hline$c_{\mathrm{p}}:$ Market T & neasure & & & & & \\
\hline $\mathrm{R}_{\mathrm{mt}}$ : Excess & ance of th & ficial Gene & $x$ of the $A$ & Stock Excl & & \\
\hline $\mathrm{R}_{\mathrm{pt}}:$ Excess & ance of the & Mutual Fu & & & & \\
\hline
\end{tabular}

Table4

Summary results from Treynor - Mazuy model for the period 1993 - 1997 with correction of heteroscedasticity according to the Newey - West method:

$R_{p t}=a_{p}+b_{p} R_{m t}+c_{p} R_{m t}^{2}+u_{p t}$

\begin{tabular}{|l|l|l|l|l|l|l|}
\hline Parameter & Positive & Negative & Statistically Significant* & Statistically Insignificant \\
\hline$\alpha_{\mathrm{p}}$ & & & Positive & Negative & Positive & Negative \\
\hline $\mathrm{b}_{\mathrm{p}}$ & 5 & 14 & 1 & 2 & 4 & 12 \\
\hline $\mathrm{c}_{\mathrm{p}}$ & 19 & - & 19 & - & - & - \\
\hline$\alpha_{\mathrm{p}}:$ Selectivity Parameter & 7 & 12 & 1 & 5 & 6 & 7 \\
\hline $\mathrm{b}_{\mathrm{p}}:$ Beta & \multicolumn{7}{l|}{} \\
\hline $\mathrm{c}_{\mathrm{p}}:$ Market Timing measure \\
$\mathrm{R}_{\mathrm{mt}}:$ Excess performance of the TPI \\
$\mathrm{R}_{\mathrm{pt}}:$ Excess performance of the $\mathrm{p}^{\text {th }}$ Mutual Fund \\
* $_{\mathrm{a}}$ a\% level
\end{tabular}

Table 5

Summary Results from Henriksson - Merton model for the period 1993 - 1997 with correction of heteroscedasticity according to the Newey - West method:

$R_{p t}=a_{p}+b_{p d} R_{m t}+b_{p o} R_{m t} D_{u t}+u_{p t}$

\begin{tabular}{|c|c|c|c|c|c|c|}
\hline \multirow[t]{2}{*}{ Parameter } & \multirow[t]{2}{*}{ Positive } & \multirow[t]{2}{*}{ Negative } & \multicolumn{2}{|c|}{ Statistically Significant* } & \multicolumn{2}{|c|}{ Statistically Insignificant } \\
\hline & & & Positive & Negative & Positive & Negative \\
\hline$\alpha_{p}$ & 12 & 7 & 2 & - & 10 & 7 \\
\hline $\mathrm{b}_{\mathrm{pd}}$ & 19 & - & 19 & - & - & - \\
\hline $\mathrm{b}_{\mathrm{po}}$ & 9 & 10 & 1 & 1 & 8 & 9 \\
\hline \multicolumn{7}{|c|}{$\alpha_{\mathrm{p}}:$ Selectivity Parameter } \\
\hline \multicolumn{7}{|c|}{$\mathrm{b}_{\mathrm{pd}}:$ Beta during down markets } \\
\hline \multicolumn{7}{|c|}{$\mathrm{b}_{\mathrm{po}}$ : Beta during up markets - Beta during down markets $\left(\mathrm{b}_{\mathrm{pu}}-\mathrm{b}_{\mathrm{pd}}\right)$} \\
\hline \multicolumn{7}{|c|}{$\mathrm{R}_{\mathrm{m} t}$ : Excess performance of the official General Index of the Athens Stock Exchange } \\
\hline \multicolumn{7}{|c|}{$\mathrm{R}_{\mathrm{pt}}:$ Excess performance of the $\mathrm{p}^{\text {th }}$ Mutual Fund } \\
\hline *at $5 \%$ leve & & & & & & \\
\hline
\end{tabular}


Table 6

Summary results from Henriksson - Merton model for the period 1993 - 1997 with correction of heteroscedasticity according to the Newey - West method:

\begin{tabular}{|c|c|c|c|c|c|c|}
\hline \multirow[t]{2}{*}{ Parameter } & \multirow[t]{2}{*}{ Positive } & \multirow[t]{2}{*}{ Negative } & \multicolumn{2}{|c|}{ Statistically Significant* } & \multicolumn{2}{|c|}{ Statistically Insignificant } \\
\hline & & & Positive & Negative & Positive & Negative \\
\hline$\alpha_{\mathrm{p}}$ & 3 & 16 & 1 & 2 & 2 & 14 \\
\hline$b_{\mathrm{pd}}$ & 19 & - & 19 & - & - & - \\
\hline $\mathrm{b}_{\mathrm{po}}$ & 11 & 8 & 1 & - & 10 & 8 \\
\hline \multicolumn{7}{|c|}{$\alpha_{\mathrm{p}}:$ Selectivity Parameter } \\
\hline \multicolumn{7}{|c|}{$\mathrm{b}_{\mathrm{pd}}$ : Beta during down markets } \\
\hline \multicolumn{7}{|c|}{$\mathrm{b}_{\mathrm{po}}$ : Beta during up markets - Beta during down markets $\left(\mathrm{b}_{\mathrm{pu}}-\mathrm{b}_{\mathrm{pd}}\right)$} \\
\hline \multicolumn{7}{|c|}{$\mathrm{R}_{\mathrm{mt}}:$ Excess performance of the TPI } \\
\hline \multicolumn{7}{|c|}{$\mathrm{R}_{\mathrm{pt}}$ : Excess performance of the $\mathrm{p}^{\text {th }}$ Mutual Fund } \\
\hline
\end{tabular}

The selectivity coefficient $\left(\alpha_{p}\right)$ estimated using the Official General Index is found to be positive for twelve mutual funds (statistically significant for two mutual funds) whereas it was negative but insignificant for the rest seven funds. Nine mutual funds exhibit positive signs for the market timing skills coefficient $\left(b_{\mathrm{po}}\right)$, one of which is found to be statistically significant, whereas ten funds exhibit negative coefficients, of which one is found to be statistically significant. The use of the TP Index reduces somewhat the ability of fund managers for selectivity.

Empirical results presented in Table (6) suggest that the number of mutual funds exhibiting positive selectivity coefficients have been reduced dramatically (only three mutual funds give positive coefficient, of which one is statistically significant). On the other hand, there are sixteen negative coefficients, two of which are found to be statistically significant. The results referring to timing ability remain almost unchanged. Eleven mutual funds exhibit positive signs for the market timing coefficient, of which one is statistically significant, whereas eight mutual funds give negative market timing ability, none of which is statistically significant.

These results are also in line with Table 1 and the related discussion, namely we do not find significant timing and selectivity abilities for most mutual fund managers. It is interesting that all models yield the same conclusion: the most successful fund in terms of selectivity is Midland's Equity Fund. Alpha Balanced Fund turns out to be best in terms of market timing.

\section{Conclusions}

This paper investigates the performance of nineteen Greek mutual fund managers in terms of "market timing" and "selectivity" for the period January 1993 to December 1997. These issues are analyzed within the framework suggested by Treynor - Mazuy (1966) and Henriksson - Merton (1981). Additionally the problem of heteroscedasticity is taken into account by using the method of Newey - West (1987). The empirical findings do not reveal any general ability of the fund managers to time the market correctly, irrespectively of how the returns of the market index are calculated. It is interesting to note that using the Total Performance Index reduces the ability of managers for selectivity. This result holds for both the models utilized in our study. Based on published information, Greek fund managers are young, relatively inexperienced and very mobile across funds. The existence of five out of nineteen mutual funds with negative statistical significant coefficient of market timing is a phenomenon attributable to the lack of experience of their managers within the short period of the life of mutual funds in Greece.

\section{Suggestions for future research}

Recent literature on mutual fund performance ${ }^{13}$ has inquired into the qualitative characteristics of mutual fund managers such as age, education, experience, etc. This line of research holds some promise in explaining the re- 
sults presented in this paper.

\section{Endnotes}

1. They provide professional management, diversification, liquidity, switching services, checking accounts, systematic accumulation and withdrawal plans, etc.

2. FEFSI 2001.

3. For an excellent discussion for the efficient market hypothesis see Fama (1970).

4. According to Chevalier and Ellison (1999), the American mutual fund managers are 44 years old in average, with a spread of 24 to 80 . The majority of them hold an MBA degree and have achieved high SAT scores.

5. For example see Treynor and Mazuy (1966), Fama (1972), Jensen (1972), Henriksson and Merton (1981), Kon (1983), Bhattacharya and Pfleiderer (1983), Chang and Lewellen (1984), Henriksson (1984), among others.

6. According to Coggin - Fabozzi - Rahman (1993) it is necessary to correct for heteroscedasticity

7. The existence of the heteroscedasticity problem requires the use of proper estimation techniques (Newey - West, White, etc.).

8. The empirical studies, which find that fund managers are able to identify undervalued assets are among others: Lockwood and Kadiyala (1988), Coggin -Fabozzi and Rahman (1993), Gallo and Swanson (1996), Daniel-et al. (1997). The empirical studies, which reveal no market timing skills are the following: Treynor and Mazuy (1966), Chang and Lewellen (1984), Henriksson (1984), Chua and Woodward (1986), Connor and Korajzcyk (1986), Grinblatt and Titman (1988), Lockwood and Kadiyala (1988), Cumby and Glen (1990), Sinclair (1990), Coggin Fabozzi and Rahman (1993), Gallo and Swanson (1996), Daniel-et all (1997) among others. For an interesting review see Allen D.E. and V. Soucik (2000).

9. According to the writers the results are consistent with those of Admati and Ross (1985) and Jagannathan and Korajzczyk (1986).

10. The relevant data were drawn from "KERDOS" database (KERDOS is an old, Greek, economic newspaper), which is the most reliable source of information for Greek Mutual Funds. The KERDOS data extend back to 1991 and they are dividend adjusted.

11. The construction of the Total Performance Index is an innovation of the present work and has not been considered before in Greek empirical studies. The TPI was constructed for the period January 41988 - December 31 1997. It has the same characteristics and incorporates the same changes with the official Athens Stock Exchange Index (See Alpha Bank Economic Bulletin, 1998) and is available upon request.

12. The database used is that of Datastream on line.

13. Chevalier and Ellison (1999). 


\section{Appendix}

Table 7

Total assets and number of mutual funds in Greece by type.

\begin{tabular}{|c|c|c|c|c|c|c|c|c|c|c|}
\hline & \multicolumn{2}{|c|}{$31 / 12 / 1999$} & \multicolumn{2}{|c|}{$31 / 12 / 1998$} & \multicolumn{2}{|c|}{$31 / 12 / 1997$} & \multicolumn{2}{|c|}{$31 / 12 / 1996$} & \multicolumn{2}{|c|}{$31 / 12 / 1995$} \\
\hline $\begin{array}{l}\text { M/F } \\
\text { Type }\end{array}$ & $\begin{array}{c}\text { Amou } \\
\text { nt } \\
\text { (bil- } \\
\text { lion } \\
\text { drach } \\
\text { mas) }\end{array}$ & $\begin{array}{l}\text { No. } \\
\text { M/F }\end{array}$ & $\begin{array}{l}\text { Amount } \\
\text { (billion } \\
\text { drachmas) }\end{array}$ & $\begin{array}{l}\text { No. } \\
\text { M/F }\end{array}$ & $\begin{array}{l}\text { Amount } \\
\text { (billion } \\
\text { drachmas }\end{array}$ & $\begin{array}{l}\text { No. } \\
\text { M/F }\end{array}$ & $\begin{array}{l}\text { Amount } \\
\text { (billion } \\
\text { drachmas) }\end{array}$ & $\begin{array}{l}\text { No. } \\
\text { M/F }\end{array}$ & $\begin{array}{c}\text { Amount } \\
\text { (billion } \\
\text { drachmas) }\end{array}$ & $\begin{array}{l}\text { No. } \\
\text { M/F }\end{array}$ \\
\hline $\begin{array}{l}\text { Money } \\
\text { Market }\end{array}$ & $\begin{array}{c}4579 . \\
2 \\
\end{array}$ & 45 & 5966.8 & 42 & 4405 & 36 & 2299 & 36 & 1259 & 21 \\
\hline Bond & $\begin{array}{c}1363 . \\
1\end{array}$ & 67 & 1680 & 64 & 2063 & 64 & 1435 & 60 & 1029 & 48 \\
\hline Equity & $\begin{array}{c}4976 . \\
6\end{array}$ & 66 & 492 & 40 & 237 & 32 & 78 & 29 & 91 & 24 \\
\hline Mixed & $\begin{array}{c}1023 . \\
5\end{array}$ & 30 & 828 & 30 & 619 & 26 & 89 & 22 & 69 & 21 \\
\hline Special & - & - & 31 & 2 & 4 & 2 & 3 & 2 & 5 & 1 \\
\hline Sum & $\begin{array}{c}11933 \\
.4\end{array}$ & 208 & 8998 & 178 & 7327 & 160 & 3874 & 148 & 2453 & 115 \\
\hline & & & & $\mathrm{J}$ & Greek In & atior & vestors & & & \\
\hline
\end{tabular}

\section{Table 8}

Total Deposits. ASE Capitalization. M/F Total Assets (billion drachmas)

\begin{tabular}{|l|l|l|l|}
\hline & Total Deposits & ASE Capitalization & M/F Total Assets \\
\hline Dec 1991 & 9233.5 & 2355.2 & 171.5 \\
\hline Dec 1992 & 10149.0 & 2044.9 & 223.4 \\
\hline Dec 1993 & 11084.6 & 3117.5 & 866.8 \\
\hline Dec 1994 & 13747.5 & 3577.9 & 1343.7 \\
\hline Dec 1995 & 15766.1 & 4026.0 & 2454.1 \\
\hline Dec 1996 & 17997.1 & 5944.8 & 3873.4 \\
\hline Dec 1997 & 19754.9 & 9811.3 & 7325.3 \\
\hline Dec 1998 & 20058.4 & 24289.0 & 8997.7 \\
\hline Jul 1999 & 21282.0 & 43608.0 & 10110.8 \\
\hline Dec 1999 & 22835.9 & 67306.5 & 11933.5 \\
\hline Source: Bank of Greece. Union of Greek Institutional Investors. \\
\hline
\end{tabular}


Table 9

The Greek Mutual Fund Industry. 1985-1999

\begin{tabular}{|l|c|c|c|c|}
\hline Date & $\begin{array}{c}\text { Management } \\
\text { Companies }\end{array}$ & $\begin{array}{c}\text { Number } \\
\text { of M/F }\end{array}$ & $\begin{array}{c}\text { Invested Funds } \\
\text { (bill. Drachmas) }\end{array}$ & $\begin{array}{c}\text { ASE General Index } \\
(31 / 12 / 1980=100)\end{array}$ \\
\hline $31 / 12 / 1985$ & 2 & 2 & 4.0 & 70.9 \\
\hline $31 / 12 / 1986$ & 2 & 2 & 4.9 & 103.9 \\
\hline $31 / 12 / 1987$ & 2 & 2 & 7.6 & 272.5 \\
\hline $31 / 12 / 1988$ & 2 & 2 & 10.5 & 279.7 \\
\hline $31 / 12 / 1989$ & 3 & 3 & 20.8 & 459.4 \\
\hline $31 / 12 / 1990$ & 7 & 7 & 146.7 & 932.0 \\
\hline $31 / 12 / 1991$ & 11 & 18 & 166.9 & 809.7 \\
\hline $31 / 12 / 1992$ & 20 & 39 & 216.6 & 672.3 \\
\hline $31 / 12 / 1993$ & 21 & 73 & 858.0 & 958.7 \\
\hline $31 / 12 / 1994$ & 24 & 96 & 1337.9 & 868.9 \\
\hline $31 / 12 / 1995$ & 25 & 116 & 2376.0 & 914.2 \\
\hline $31 / 12 / 1996$ & 29 & 150 & 3789.0 & 933.5 \\
\hline $31 / 12 / 1997$ & 29 & 161 & 7319.0 & 1479.6 \\
\hline $31 / 12 / 1998$ & 30 & 178 & 8997.7 & 2738.0 \\
\hline $31 / 12 / 1999$ & 30 & 208 & 11993.5 & 5535.1 \\
\hline
\end{tabular}

\section{Acknowledgements}

The author wishes to thank Professors N. Pittis and E. Tsiritakis and an anonymous referee for their comments and suggestions.

\section{References}

1. Admati A. and S. Ross "Measuring Investment Performance in a Rational Expectations Equilibrium Model", Journal of Business, Vol. 58, No. 1, pp. 1-26, 1985.

2. Allen D.E. and V. Soucik "In Search of True Performance: testing Benchmark-Model Validity in Managed Funds Context", Working Paper, School of Finance and Business Economics, Edith Cowan University, 2000.

3. Bhattacharya S. and P. Pfleiderer, "A Note on Performance Evaluation", Technical Report 714 Stanford, Calif: Stanford University, Graduate School of Business, 1983.

4. Black F., M. Jensen and M. Scholes "The Capital Asset Pricing Model: Some Empirical Tests", In M. Jensen Editor: Studies in the Theory of Capital Markets, New York, Praeger, 1972.

5. Blume M. and I. Friend "A New Look at the Capital Asset Pricing Model”, Journal of Finance, Vol. 28, No. 1, pp. $19-33,1973$.

6. Breen W, R. Jagannathan and A. Ofer "Correcting for Heteroscedasticity in Tests for Market Timing Ability”, Journal of Business, Vol. 59, No. 4, pp. 585 - 598, 1986.

7. Chang E. and W. G. Lewellen "Market Timing and Mutual Fund Investment Performance", Journal of Business, Vol. 57, No. 1, pp. 57-72, 1984.

8. Chevalier J. and G. Ellison "Are Some Mutual Fund Managers Better than Others? Cross Sectional Patterns in Behavior and Performance”, Journal of Finance, Vol. 54, No.3, pp. 875 - 899, 1999.

9. Chua J.H. and R.S. Woodward "Gains from Market Timing”, Monograph No 1986 - 2, New York University, 1986. 
10. Coggin D., F. Fabozzi, S. Rahman "The Investment Performance of US Equity Pension Fund Managers: An Empirical Investigation”, Journal of Finance, Vol.48, No. 3, pp. 1039 - 1055, 1993.

11. Connor G. and R.A. Korajzcyk "Performance Measurement with the Arbitrage Pricing Theory: A New Framework for Analysis", Journal of Financial Economics, Vol. 15, No. 3, pp. 374 - 394, 1986.

12. Connor G. and R.A. Korajzcyk "The Attributes Behavior and Performance of U.S. Mutual Funds". Review of Quantitative Finance Accounting, pp. 5-26, 1991.

13. Cumby R. and J. Glen "Evaluating the Performance of International Mutual Funds", Journal of Finance, Vol. 45, No. 2, pp. 497 - 521, 1990.

14. Daniel K.et al. "Measuring Fund Performance with Characteristic-Based Benchmarks", Journal of Finance, Vol. 52, No. 3, pp. 1035 - 1058, 1997.

15. Fama E. "Efficient Capital Markets: A Review of Theory and Empirical Work", Journal of Finance, Vol. 25, No. 2, pp. $383-417,1970$.

16. Fama E. "Components of Investment Performance”, Journal of Finance, Vol. 27, No. 2, pp. 551-567, 1972.

17. Gallo J. and P. Swanson "Comparative Measures of Performance for US Based International Equity Mutual Funds", Journal of Banking and Finance, Vol. 20, No. 10, pp. 1635-1650, 1996.

18. Grinblatt M. and S. Titman "Mutual Fund Performance: An Analysis of Monthly Returns", Working Paper, University of California, Los Angeles, 1988.

19. Henriksson R. "Market Timing and Mutual Fund Performance: An Empirical Investigation", Journal of Business, Vol. 57, No.1, pp. 73-96, 1984.

20. Henriksson R. and D.L. Lessard "The Efficiency of the Forward Exchange Market: A Conditional NonParametric Test of Forecasting Ability", Finance Series Working Paper No. 130, University of California, Berkeley CA. 1982.

21. Henriksson R. and R. Merton "On Market Timing and Investment Performance”, Journal of Business, Vol. 57, No. 4, pp. 513-534, 1981.

22. Hildreth C. and C. Houck "Some Estimators for a Linear Model with Random Coefficients", Journal of the American Statistical Association, Vol. 63, No. 322, pp. 584 - 595, 1968.

23. Jagannathan R and R.A. Korajzcyk "Assessing the Market Timing Performance of Managed Portfolios", Journal of Business, Vol. 59, No. 2, pp. 217 - 235, 1986.

24. Jensen M. "The Performance of Mutual Funds in the Period 1945 - 1964", Journal of Finance, Vol. 23, No. 2, pp. $389-461,1968$.

25. Jensen M. "Risk, the Pricing of Capital Assets and the Evaluation of Investment Portfolios", Journal of Business, Vol. 42, No. 2, pp. 167 - 247, 1969.

26. Jensen M. "Optimal Utilization of Market Forecasts and Evaluation of Investment Performance", G.P. Szego and K. Shell eds, Mathematical Methods of Investment and Finance, North - Holland Amsterdam, 1972.

27. Koh F., K.F. Phoon and C.H. Tan "Market Timing Abilities of Fund Managers: Parametric and non Parametric Tests" Journal of Business, Finance and Accounting, Vol. 20, No. 2, pp. 155 - 166, 1993.

28. Kon S. J. "The Market Timing Performance of Mutual Fund Managers", Journal of Business, Vol. 56, No. 3, pp. 323-348, 1983.

29. Kon S. J. and F.C. Jen, "The Investment Performance of Mutual Funds: An Empirical Investigation of Timing, Selectivity and Market Efficiency", Journal of Business, Vol. 52, No. 2, pp. 263-290, 1979.

30. Lee C. and S. Rahman "Market Timing, Selectivity and Mutual Funds Performance: An Empirical Investigation", Journal of Business, Vol. 63, No. 2, pp. 261 - 278, 1990.

31. Lehmann, B. N., and D. M. Modest "Mutual Fund Performance Evaluations: A Comparison of Benchmarks and Benchmarks Comparisons", Journal of Finance, Vol. 42, No. 2, pp. 233-265, 1987.

32. Lintner J. "The Valuation of Risk Assets and the Selection of Risky Investments in Stock Portfolios and Capital Budgets", Review of Economics and Statistics, Vol. 47, No. 1, pp. 13-17, 1965.

33. Lockwood L. and R. Kadiyala "Measuring Investment Performance with a Stochastic Parameter Regression Model", Journal of Banking and Finance, Vol. 12, No.3, pp. 457 - 467, 1998.

34. Merton R.C. "On Market Timing and Investment Performance. I. An Equilibrium Theory of the Value for Market Forecasts", Journal of Business, Vol. 54, No. 3, pp. 363-406, 1981.

35. Milonas, N. "Greek Mutual Funds. Theory and Practice", A.N. Sakkoulas Publications, 1999. 
36. Mossin J. "Equilibrium in a Capital Asset Market", Econometrica, Vol. 34, No. 4, pp. 768 - 783, 1966.

37. Newey W.K. and K. West "Hypothesis Testing with Efficient Method of Moments Estimation", International Economic Review, Vol. 28, No. 3, pp. 777-787, 1987.

38. Newey W.K. and K. West "A Simple Positive Semi - Definite Heteroscedasticity and Autocorrelation Consistent Covariance Matrix", Econometrica, Vol. 55, No.5, pp. 703-708, 1987.

39. Philippas, N. "Construction and Analysis of a Total Performance Index for the Athens Stock Exchange", Alpha Bank Economic Bulletin, pp.22 - 31, 1998.

40. Philippas, N. "Mutual Funds and the Stock Exchange Environment" Globus Invest Editions, Athens, 1999.

41. Sharpe W.F. "Capital Asset Prices: A Theory of Market Equilibrium Under Conditions of Risk", Journal of Finance, Vol. 19, No. 4, pp. 425 - 442, 1964.

42. Sinclair N.A. "Market Timing Ability of Pooled Superannuation Funds", Accounting and Finance, pp. 51 65, 1990.

43. Treynor J.L. and J. Mazuy "Can Mutual Funds Outguess the Market?" Harvard Business Review, Vol. 44, No. 4, pp. $131-136,1966$. 